\title{
INTERNALISASI NILAI-NILAI CINTA TANAH AIR PADA EKSTRAKURIKULER IRMAS AL FIKRI DI SMKN 1 LEMAHABANG
}

Luthfiah

Institut Agama Islam Bunga Bangsa Cirebon, Jawa Barat, Indonesia

luthfiahannaziiha@gmail.com

\begin{tabular}{|c|c|}
\hline Received: & 11-01-2022 \\
\hline Accepted: & 11-01-2022 \\
\hline Published: & 20-01-2022 \\
\hline Keywords: & $\begin{array}{l}\text { internalization; } \\
\text { values of love of } \\
\text { the homeland; } \\
\text { irmas }\end{array}$ \\
\hline
\end{tabular}

\section{Abstract}

This thesis is motivated by the national problem, namely intolerance. Intolerance often ends in conflict and violence in the school environment so that it poses a fatal threat to the future of the younger generation and the quality of education in Indonesia, so schools must determine special strategies to overcome this problem. This study aims to discover the values of love for the homeland, which were internalized by Irmas Al Fikri. In addition, it is to know the strategy for internalizing the values of love to the homeland in Irmas Al Fikri and to comprehend the cognitive perceptions of Irmas Al Fikri members.

This study applied a qualitative descriptive approach. This study uses primary data sources and secondary data sources from extracuriculer activities at Irmas Al Fikri SMKN 1 Lemahabang. The data was collected through a field study research design. To analyzing the data, this study applied reduction stage through code analysis, data display, verification and conclusion.

The results of this study indicate that the form of internalization of the values of patriotism that have been realized in Irma Al Fikri include Indonesian studies, rihlah, social service, and basic leadership training based on national values including loving diversity/difference, developing a sense of kinship with the spirit of cooperation, tolerance, care for the environment, social care, and responsibility.

The conclusion in the process of internalizing the value of love for the homeland is still not evenly distributed among all members, because there are still members who do not fully understand the basic meaning of the state (Pancasila) but the administrators and coaches are committed to continuing to maximize and evenly distribute all levels of Irmas Al Fikri members.

\begin{tabular}{ll}
\hline & \\
\hline Kata & internalisasi; \\
kunci: & nilai-nilai cinta \\
& tanah air; irmas
\end{tabular}

Abstrak

Skripsi ini dilatarbelakangi oleh problematika kebangsaan yakni intoleransi. Sikap intoleransi kerap berakhir pada konflik dan kekerasan di lingkungan sekolah sehingga memiliki ancaman serius bagi masa depan generasi muda dan kualitas pendidikan di Indonesia maka sekolah harus menentukan startegi khsusus untuk mengatasi ini.

Tujuan penelitian ini adalah untuk mengetahui nilainilai cinta tanah air yang diinternalisasikan Irmas Al Fikri, mengetahui strategi internalisasi nilai-nilai cinta 
tanah air pada Irmas Al Fikri, mengetahui persepsi kognitif anggota Irmas Al Fikri.

Penelitian ini menggunakan pendekatan kualitatif dengan jenis penelitian deskriptif. Penelitian ini menggunakan sumber data primer dan sumber data sekunder dari kegiatan ekstrakurikuler Irmas Al Fikri SMKN 1 Lemahabang. Data dikumpulkan dengan teknik studi lapangan. Analisis data dilakukan dengan tahapan reduksi data melalui analisis kode, penyajian data, verifikasi dan kesimpulan.

Hasil penelitian ini menunjukkan bahwa bentuk internalisasi nilai-nilai cinta tanah air yang telah terealisasikan pada Irmas Al Fikri diantaranya yaitu kajian keindonesiaan yang dilaksanakan setiap satu bulan dua kali, rihlah ke tempat ibadah agama lain, bakti sosial terhadap masyarakat sekitar, dan latihan dasar kepemimpinan. Kegiatan tersebut tentunya berlandaskan nilai-nilai kebangsaan meliputi mencintai keberagamana atau perbedaan, mengembangkan rasa kekeluargaan dengan semangat gotong royong, toleransi, peduli lingkungan, peduli sosial, dan tanggung jawab.

Kesimpulan pada proses internalisasi nilai cinta tanah air masih belum merata keseluruh anggota, karena masih ada anggota belum memahami betul makna dasar negara (pancasila) sehingga perlu adanya evaluasi lebih lanjut untuk memaksimalkan proses internalisasi ini. Berkenaan dengan hal tersebut pengurus dan pembina berkomitmen untuk terus memaksimalkan dan merata keseluruh lapisan anggota Irmas Al Fikri.

Corresponding Author: Ita Lailasari E-mail: italailasario82@gmail.com

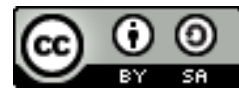

\section{PENDAHULUAN}

Dewasa ini Indonesia tengah dihadapkan pada problematika kebangsaan yakni intoleransi. Sikap intoleransi kerap berakhir pada konflik dan kekerasan di masyarakat, demikian juga menjamurnya gerakan-gerakan keagamaan fundamentalis bahkan radikal. Ironisnya, sekolah sebagai sarana menyemaikan nilai-nilai kebaikan, ditengarai sejumlah penelitian terkadang juga dijadikan oleh sebagian|orang yang tidak bertanggungjawab. Sebagai tempat penyebaran paham-paham ekstrim pada generasi muda. Tidak bisa dipungkiri efek negatif global digital sangat sistemik dan melintas batas (politik, ekonomi, sosial, budaya, agama, keamanan) yang menyebabkan transformasi informasi yang tidak dapat di pertanggungjawabkan akhirnya, sering digunakan pada ideology radikalisme mentransmisikan ajaran kekerasan, merekrut partisipan dan mendoktrin anak-anak muda agar berpandangan sempit dan intoleran kepada kemajemukan. Penyusupan ideologi memang menjadi sarana utama yang 
bertujuan menanamkan nila-nilai kebencian, intoleran, sikap agresif yang mengarah ke kekerasan, dan itu bertentangan dengan ideologi pancasila.

Kondisi ini diperparah dengan realitas sosiologis yang sangat mengenaskan pasca reformasi di negara ini. Terutama ketika kran demokrasi dibuka sebebas-besanya, menurut analisis beernhard platzdasch dalam penelitiannya berjudul Islamism in Indonesia politics in the emergencing democracy- kondisi ini telah memunculkan instabilitas sosial politik dan menimbulkan sejumlah konflik etnis serta memberi angin segar pada kelompok-kelompok agama ekstrimis-radikal (Platzdasch, 2009).

Berdasarkan data yang diterima setelah melakukan studi lapangan siswa SMKN 1 Lemahabang banyak yang terbawa arus negatif sosial media. Fenomena tersebut diperparah dengan merembesannya bibit-bibit ekstrimisme dalam dunia pendidikan yang memiliki ancaman serius bagi masa depan generasi muda dan kualitas pendidikan|di|Indonesia. Peneliti kawakan dari LIPI Anas Saidi mengatakan "Radikalisme ideologi telah merambah dunia sekolah dan berpotensi memecah belah bangsa”. Anas juga menunjukkan; bahwa 25\% siswa dan 21\% guru menyatakan pancasila tidak lagi relevan (Saidi, 2016). (Dja'far, 2015), peneliti wahid institut merujuk pada penelitian LaKiP juga menunjukkan menguatnya sikap intoleransi disekolah.

Begitupula hasil penelitian yang dilakukan lembaga kajian islam dan perdamaian (LaKiP) Jakarta, pada oktober 2010 hingga 2011 terhadap guru PAI dan siswa (SMP dan SMA) di Jabodetabek. Hasilnya sungguh mengejutkan bahwa 49\% siswa setuju dengan aksi radikalisme demi agama (Gunaryo, 2011). Hasil riset BIN tahun 2017 diketahui 24\% mahasiswa dan $23,3 \%$ pelajar SMK sederajat setuju dengan tegaknya negara islam diIndonesia (Purbaya, 2018). Bahkan, di Kabupaten Semarang Jawa Tengah, beberapa tahun lalu sebuah yayasan Pendidikan Islam pernah memecat 13 Guru karena mengajarkan paham radikal (Lestrasi, 2016). Adanya darurat intoleransi, terutama di wilayah Jawa Tengah.

Guna mengantisipasi masuknya ekstrimisme dan radikalisme dalam dunia pendidikan, pemerintah melalui kementrian pendidikan nasional sebenarnya telah menemukan antisipasi dengan menekankan kurikulum yang berbentuk nilai-nilai nasionalisme dan kebangsaan pada peserta didik. Perubahan ini tidak hanya dilakukan di perguruan tinggi namun juga di jenjang sekolah dasar hingga menengah (Tilar: 2005). Mendikbud Muhadjir Effendy pernah mengaku telah berkoordinasi dengan Kementrian agama untuk meninjau ulang kurikulum pendidikan agama disekolah terkait fenomena tumbuhnya benih radikalisme di lingkungan sekolah (Wicaksono \& Dermawan, 2020). Kemenag baru-baru ini telah melakukan FGD (Forum Group Discussion) terkait penyusunan buku moderasi beragama untuk menangkal gerakan radikalisme. Apalagi kebijakan Kemendikbud yang terbaru juga inline dengan Kemendikbud sebelumnya bahwa secara umum tujuan dari pendidikan adalah memberi pemahaman wawasan kebangsaan dan bela negara (UUD 1945, Pancasila, Bhineka Tunggal Ika dan NKRI). Pendidikan diorientasikan untuk penciptaan karakter unggul, budaya akademik kolaboratif dan kompetitif serta pengembangan kecerdasan (Civic Intellegence), tanggung jawab (Responsibility) dan partisipas (Civic Participation) warga negara sebagai landasan pengembangan nilai dan perilaku demokrasi.

Ada beberapa hal yang dapat dilakukan untuk mencegah paham radikalisme ke ruang publik: pertama, peran pemerintah harus tegas menentang kelompok-kelompok agama yang terbukti menyebarkan kebencian, fitnah, dan saling memerangi. Kedua, peran serta masyarakat khususnya pemuka agama sangat diperlukan agar khutbah 
selalu menekankan pentingnya ukhuwah dan cinta tanah air. Ketiga, membangun kembali pendidikan agama dan memperluas persatuan dan toleransi antar umat beragama kepada siswa.

Pelajar sebagai generasi muda penerus bangsa|merupakan generasi emas yang harus dipersiapkan dari awal agar membuahkan hasil memuaskan di masa mendatang. Salah satu hal yang harus dilakukan adalah menyelamatkannya dari doktrin radikalisme agama yang menyimpang. Karena hal inilah, Ketua TP PKK Provinsi Jawa Barat, Atalia Ridwan|Kamil mengajak seluruh|pelajar, terutama yang ada di wilayah Jawa Barat, untuk bergerak|bersama memberantas radikalisme (JSH, 2020).

Internalisasi nilai cinta tanah air merupakan salah satu upaya nyata untuk mengatasi perilaku intoleran. Selama lebih dari tujuh tahun, Indonesia telah menjadi negara merdeka. Namun, di era kemerdekaan yang panjang ini, nasionalisme atau cinta tanah air Indonesia telah menjadi modal pendorong kemerdekaan belum kokoh.

Sebagai penerus warga negara dan negara Indonesia, hendaknya kita menunjukkan sikap dan perilaku yang bermanfaat bagi kepentingan masyarakat, dan menghindari penyimpangan sosial yang dapat merusak norma dan nilai budaya Indonesia, karena penyimpangan tidak hanya merugikan diri kita sendiri, tetapi juga dapat merugikan masyarakat bahkan Negara.

Doni Koesoema: “Tanpa kemerdekaan, tidak akan ada bangsa yang bertanggung jawab. Jika tidak ada semangat kemerdekaan atau kemauan merdeka dalam mentalitas bangsa, tidak akan ada kemerdekaan. Oleh karena itu, jika syarat utama yaitu kemerdekaan tidak dikedepankan, maka hakikat bangsa tidak akan terwujud" (Albertus, 2010).

Pancasila diciptakan sebagai dasar dan ideologi negara, dan itu akan membimbing kita untuk Berperilaku sebagai warga negara yang baik. Sebagai negara yang merdeka, Pancasila mengandung dasar cita-cita kemerdekaan Indonesia. Sebagai hasil perjuangan rakyat Indonesia untuk persatuan, kemerdekaan harus dipertahankan. Indonesia yang merdeka harus memiliki dasar, dan negara yang dimiliki bersama oleh semua dan semua orang akan dibangun di atas fondasi yang unggul ini (Putra, 1995).

Pancasila sendiri mengandung nilai-nilai luhur yang harus tertanam pada diri seseorang|sebagai wargan negara, yaitu nilai agama, nilai budaya, nilai|pendidikan dan nilai kebangsaan atau nasionalisme.

Cinta tanah air merupakan salah satu hal tama dalam membentuk sebuah karakter warga negara, kemudian rasa memiliki, rasa menjaga, rasa melestarikan, rasa ingin memajukan akan tumbuh dan bermula dari sikap cinta tersebut. Sebagai warga negara, ia memiliki tanggung jawab untuk memupuk rasa cinta tanah air, karena di situlah letak budaya dan sejarahnya. Oleh karena itu, sebagai warga negara, kita harus mendedikasikan diri untuk negara kita mulai dari mencintai tanah air. Tidak hanya diungkapkan secara lisan dalam bentuk kata-kata, tetapi juga diwujudkan dalam upaya meningkatkan gaya hidup bangsa.

Mukhlas Samani dan Haryanto mengatakan: "Cinta tanah air adalah cinta dan pengabdian kepada tanah, peduli pertahanannya, dan bersiap berkorban untuk keutuhan tanah." (Samani \& Hariyanto, 2011) Menurut Akhmad Muhaimin Azzel, "salah satu tanda seseorang memiliki sikap cinta tanah air adalah kemampuan mengapresiasi seni dan budaya bangsa Indonesia” (Azzel, 2011).

Orang yang dapat mengapresiasi karya seni dan budaya biasanya memiliki sikap mampu menghargai karya, kesabaran, dan kearifan orang lain. Hal ini dapat 
Luthfiah

Internalisasi Nilai-Nilai Cinta Tanah Air pada Ekstrakurikuler Irmas Al Fikri di SMKN 1 Lemahabang

menumbuhkan rasa cinta seseorang terhadap bangsa dan negaranya sendiri, sehingga menimbulkan rasa nasionalisme.

Cinta untuk rumah sama dengan cinta antar manusia. Mengasihi sesama juga merupakan bentuk mengasihi Tuhan. Saling menasihati, tetap bersilaturahmi, saling mengunjungi, dan saling memberikan kehadiran yang saling menyayangi. Jika tidak ada cinta antara dua orang, maka tidak ada hubungan, persahabatan, nasihat, kunjungan, atau pemberian. Banyak bentuk kesenangan dan hiburan duniawi diperbolehkan dan merupakan sumber imbalan.

Islam adalah agama universal yang menjunjung tinggi nilai-nilai kemanusiaan, termasuk nilai-nilai kemanusiaan bagi negara. Arti mencintai tanah air bermula dari peristiwa terkenal yaitu Nabi SAW diusir dari Mekah. Ketika dia hendak meninggalkan Mekah, dia menoleh ke Ka'bah dan berkata: "Demi Allah, sesungguhnya aku mengetahui bahwa engkau adalah tanah Allah yang paling Dia cintai, lembah terbaik yang ada di atas muka bumi dan yang paling dicintai oeh Allah. Seandainya penduduk tidak mengusirku, aku pasti takkan pernah meninggalkanmu" (Ali, 2010).

Posisi nilai-nilai cinta tanah air dan Pendidikan karakter menjadi pintu masuk bagi tindakan masyarakat. Keduanya memainkan peran penting dalam pengembangan kepribadian. Padahal globalisasi telah membawa perubahan positif dan negatif. Tetapi tampaknya memiliki keunggulan dibandingkan sisi negatifnya. Karena|mengapa ada beberapa faktor yang mempengaruhi, misalnya masih kurangnya pengawasan orang tua atau lingkungan di luar rumah. Oleh karena itu, pemerintah mengambil tindakan cepat untuk melakukan beberapa pembenahan di bidang pendidikan, yaitu melalui revolusi spiritual yang tertuang dalam kurikulum K13, yang bertujuan untuk menumbuhkan karakter sejak dini. Selain itu, karakter dapat ditumbuhkan dengan menginternalisasi nilai-nilai patriotik melalui kegiatan belajar dan kegiatan di luar sekolah.

Internalisasi adalah penghayatan yang mendalam, pendalaman, dan penguasaan melalui kepemimpinan, kepemimpinan, dll. Oleh karena itu, internalisasi adalah proses penanaman sikap ke dalam diri seseorang melalui kepemimpinan, kepemimpinan, dll, yang dapat tercermin dalam standar sikap dan perilaku sebagai mengharapkan. (Ponsti).

Pada saat yang sama, internalisasi yang terkait dengan cinta rumah dapat dijelaskan sebagai proses mengintegrasikan sepenuhnya nilai-nilai cinta rumah ke dalam hati, sehingga hati dan jiwa dapat bergerak atas dasar doktrin mencintai rumah. Internalisasi nilai cinta rumah dicapai melalui pemahaman ajaran Islam secara menyeluruh, dan terus menyadari pentingnya mencintai rumah, dan menemukan kemungkinan untuk mewujudkannya dalam kehidupan nyata.

Internalisasi semacam ini dapat dilakukan melalui pintu-pintu kelembagaan, yaitu melalui pintu-pintu kelembagaan yang ada, seperti Lembaga Penelitian Islam. Kedua, pintu pribadi, yaitu melalui pintu pribadi, khususnya pintu guru, dan pintu untuk memperoleh bahan ajar atau mata pelajaran melalui sarana materi, tidak terbatas pada mata pelajaran agama Islam saja, tetapi juga mencakup kegiatan keagamaan di sekolah. Kegiatan dari sekolah dapat memberikan layanan bagi siswa melalui kegiatan ekstrakurikuler sekolah.

Menurut Kamus Besar Bahasa Indonesia, kegiatan ekstrakurikuler selain kegiatan kedinasan, sedangkan mata kuliah berkaitan dengan mata kuliah (KBBI, 2021). Oleh karena itu, konsep kegiatan ekstrakurikuler adalah kegiatan ekstrakurikuler, dan 
pemisahan atau bagian dari pengajaran universitas atau sekolah menengah bukan merupakan bagian dari mata pelajaran yang ditentukan dalam kurikulum.

Kegiatan ekstrakurikuler adalah kegiatan yang dilakukan di luar jam pelajaran wajib, tujuannya untuk memperdalam dan memperluas pengetahuan siswa, terutama untuk menumbuhkan moral dan karakter siswa. Dalam kegiatan ekstrakurikuler terdapat kegiatan yang bersifat umum yaitu yang pembinaannya lebih menitikberatkan pada pembentukan jiwa intelektual siswa, dan ada pula kegiatan yang bersifat keagamaan, yang bertujuan untuk menanamkan intelektual dan jiwa siswa. Mahasiswa mewujudkan nilai-nilai keislaman dalam setiap kegiatannya. Kegiatan Irmas Al Fikri bertujuan untuk membimbing siswa dalam mengamalkan ajaran agama yang diperoleh melalui kegiatan pembelajaran di kelas, serta berbagai insentif untuk membentuk kepribadian siswa berdasarkan nilai-nilai agama Islam. Dengan kata lain, tujuan utama kegiatan Irmas Al Fikri adalah untuk mendidik manusia, cinta tanah air dan takut akan Tuhan. Mahasiswa tidak hanya harus memiliki ilmu, tetapi juga harus memiliki orangorang yang menegakkan perintah agama, menjauhi larangan, dan cinta tanah air.

Beberapa uraian di atas menunjukkan bahwa kegiatan Irmas Al Fikri memegang peranan yang sangat penting dalam dunia pendidikan. Selain itu, kegiatan Irmas Al Fikri dapat dijadikan sebagai salah satu cara untuk menginternalisasikan nilai-nilai patriotik, karena dengan mengalami suatu peristiwa siswa dapat lebih memahami keadaan, dan juga dapat menerapkan ilmunya dalam praktik dan menerapkan nilai-nilai yang sesuai dengan dirinya dalam kehidupan sehari-hari. kehidupan sehari-hari. agama islam dan cinta tanah air yang telah ditanamkan dalam diri anggota melalui berbagai kegiatan Irmas.

\section{METODE PENELITIAN}

Penelitian adalah suatu proses kegiatan yang bertujuan untuk menemukan fakta melalui langkah-langkah tertentu, sehingga dapat menemukan sesuatu secara cermat dan kritis.

Keinginan untuk memahami sesuatu dengan seksama adalah karena sebuah pertanyaan yang membutuhkan jawaban yang benar. Fokus penelitian adalah pada pertanyaan yang digariskan dalam pertanyaan penelitian, yang berasal dari penyelidikan situasi yang mencurigakan. Sekaran mendefinisikan penelitian sebagai kegiatan yang dilakukan secara terorganisir, sistematis, berbasis data, kritis, dan ilmiah untuk memperoleh jawaban atau pemahaman yang lebih mendalam tentang masalah (Sekaran \& Bougie, 2016).

Creswell mendefinisikan penelitian sebagai proses siklus yang dimulai dengan mengidentifikasi masalah atau topik penelitian. Setelah masalah diidentifikasi, maka akan meninjau bacaan atau literatur, kemudian menentukan dan memperjelas tujuan penelitian, dan kemudian melakukan pengumpulan dan analisis data. Kemudian menginterpretasikan data yang diperoleh (Creswell, 2008).

Penelitian ini menggunakan metode yang disebut metode kualitatif. Kualitatif mengacu pada hal-hal yang berkaitan dengan kualitas, nilai, atau makna fakta. Kualitas, nilai, atau makna hanya dapat diungkapkan dan dijelaskan melalui linguistik, bahasa, atau tulisan. Creswell mendefinisikan penelitian kualitatif sebagai fenomena inti. Untuk memahami fenomena inti, proses wawancara dilakukan dengan partisipan atau informan penelitian dengan mengajukan pertanyaan umum dan lebih umum.

Kemudian mengumpulkan informasi yang disampaikan oleh para peserta. Informasi ini biasanya diberikan dalam bentuk teks atau teks (Creswell, 2008). Oleh karena itu, data 
yang digunakan tidak berupa angka, angka, skor atau nilai numerik; peringkat atau frekuensi biasanya dianalisis dengan perhitungan matematis atau statistik. Penelitian kualitatif adalah proses penelitian yang melibatkan partisipan, peneliti dan pembaca, serta hubungan yang mereka bangun. Oleh karena itu, penelitian akan dipengaruhi oleh lingkungan sosial, sejarah, dan budaya di mana penelitian itu dilakukan.

Penelitian kualitatif mengkaji perspektif peserta dengan strategi interaktif dan fleksibel. Penelitian kualitatif bertujuan untuk memahami fenomena sosial dari perspektif partisipan (Hermawan, 2019). Dalam penelitian kualitatif, peneliti menjadi alat utama pengumpulan data lapangan. Kecuali peneliti sendiri, tidak ada alat pengungkapan data kualitatif yang paling fleksibel, artinya alat terpenting bagi manusia adalah peneliti sebagai pengumpul data utama. Oleh karena itu, bacaan yang komprehensif dan mutakhir merupakan syarat mutlak bagi peneliti untuk mempelajari dan memecahkan teori-teori yang berkaitan dengan masalah, menganalisisnya, dan mengkonstruksi objek penelitian secara lebih jelas.

\section{HASIL DAN PEMBAHASAN}

Irmas Al Fikri memiliki banyak nilai cinta tanah air yang dapat ditanamkan kepada anggotanya. Pada setiap pertemuan pengurus berupaya untuk menanamkan nilai karakter kepada peserta didik terutama karakter cinta tanah air. Hal ini terlihat dari beberapa uraian di bawah ini:

1. Nilai nilai cinta tanah air yang terinternalisasikan pada Irmas Al Fikri yaitu mencintai keberagamana/perbedaan, mengembangkan rasa kekeluargaan dengan semangat gotong royong, toleransi, peduli lingkungan, peduli sosial, dan tanggung jawab. Hal ini sejalan dengan makna dari karakter cinta tanah air yaitu: cara berpikir, dan berbuat yang menunjukkan kesetiaan, kepeduliaan, dan penghargaan yang tinggi terhadap bahasa, lingkungan fisik, sosial, budaya, ekonomi dan politik. Perbedaan penelitian ini dengan penelitian yang ditulis oleh zidni muzaki yaitu melalui lagu-lagu daerah karena menurut zidni muzaki dengan menggunakan lagulagu daerah yang dikombinasikan dengan tari tradisional salah satu nilai cinta tanah air.

Sedangkan perbedaan yang ditemukan dengan penelitian mujazirotus syariah dengan menghormati bendera merah putih bangga terhadap bangsa dan negara ada perbedaan mencolok yaitu jika penelitian terdahulu objeknya siswa madrasah ibtidaiyah sedangkan penelitian ini objeknya adalah anggota irmas pada tingkat SMK.

Penelitian yang ditulis oleh Joko Praseto Hadi memiliki kesamaan yaitu pada ekstrakurikuler keagamaan, yang membedakan yaitu pada nilai yang diinternalisasikan. Jika penelitian joko berfokus pada proses internalisasi nilai-nilai keagamaan penelitian kali ini yaitu mengenai nilai-nilai cinta tanah air pada ekstrakurikuler keagamaan.

2. Strategi yang dilakukan Irmas Al Fikri dalam upaya internalisasi nilai cinta tanah air yakni melalu program kerja seperti kegiatan mentoring, kajian keindonesiaan, rihlah, bakti sosial, dan latihan dasar kepemimpinan. Pada penelitian zidni strategi yang digunakan yaitu melalui latihan drumband yang mana untuk menghasilkan nada yang menyatu maka perlu adanya kerjasama antar anggota sehingga dalam prosesnya anggota dibiasakan untuk saling melengkapi dan mengingatkan maka 
tumbuhkan sikap kekeluargaan yang mana sikap tersebut merupakan salah satu nilai cinta tanah air.

Strategi internalisasi nilai cinta tanah air pada penelitian Mujazirotus Syariah terlihat sangat berbeda karena dalam prosesnya dilakukan ketika proses pembelajaran berupa kegiatan pembiasaan menyanyikan lagu-lagu nasional sebelum memulai kegiatan pembelajaran.

Selanjutnya penelitian Joko Praseto Hadi, strategi yang digunakan dalam internalisasi nilai cinta tanah air menggunakan metode keteladanan, pembiasaan, pengawasan, nasihat dan berupa teguran/sanksi. Dalam pelaksanaannya siswa membiasakan diri dalam melakukan kegiatan kesehariannya yang sesuai dengan ajaran agama Islam. Kemudian internalisasi nilai-nilai agama islam juga dapat membantu dalam menekan kenakalan remaja dan dapat mencegah pengaruh buruk pada karakter siswa. Selain itu juga terlihat implikasi yang dihasilkan dalam proses internalisasi nilai-nilai agama islam melalui kegiatan eksrakurikuler keagamaan terhadap pembentukan karakter dari segi nilai mata pelajaran agama islam yang terdiri dari mata pelajaran qur'an hadits, aqidah akhlak, fiqih dan SKI .

3. Hasil dari beberapa tahapan yang telah dilaksanakan dari penelitian kali ini berbeda dengan ketiga penelitian pembanding, penelitian Zidni Muzaki menyebutkan siswa SDN 1 Pacitan belum maksimal dan masih perlu pembiasaan untuk menghasilkan generasi yang cinta tanah air, maka dari itu setiap ada acara diutamakan lagu-lagu kebangsaan.

Adapun penelitian Mujazirotus Syariah implementasi pendidikan karakter cinta tanah air dan semangat kebangsaan melalui pembiasaan menyanyikan lagu nasional kelas II SD Nurul Islam Purwoyoso Ngaliyan Semarang sudah berjalan dengan baik maka kegiatan ini bida terus dilanjutkan untuk generasi berikutnya.

Sedangkan penelitian Joko Praseto meskipun terdapat perbedaan yang mencolok yakni nilai-nilai islam menghasilkan dampak langsung dengan membiasakan diri pada kegiatan sehari-hari yang sesuai dengan nilai-nilai agama islam, tapi juga berdampak pada prestasi akademiknya.

Ketiga perbedaan diatas membuktikan bahwa penelitian ini belum dilakukan di instansi manapun. Hasil dari strategi yang telah dilaksanakan mengenai persepsi kognitif pada penelitian ini anggota Irmas Al Fikri keterserapan nilai cinta tanah air belum merata keseluruh anggota, karena masih ada anggota yang belum memahami betul makna yang terkandung didalam pancasila yang merupakan dasar negara. Sehingga diperlukan upgrading agar proses internalisasi berjalan secara maksimal dan seluruh anggota mampu memahami dan mengimplementasikan makna yang terkandung dalam nilai-nilai cinta tanah air.

Selain itu tujuan dari adanya kegiatan ekstrakurikuler sebagai wadah untuk syiar keagamaan Irmas juga salah satu ekstrakurikuler yang menanamkan nilai-nilai kebangsaan. Jadi pihak sekolah berupaya memaksimalkan kegiatan yang sudah dijalankan khususnya Irmas Al Fikri. Sehingga nantinya akan membentuk siswa yang generasi muda yang handal dan tangguh di bidang keagamaan dan kebangsaan sehingga ketika lulus nantinya sudah siap nantinya untuk diterjunkan di Masyarakat.

Pengembangan atau pembentukan nilai cinta tanah air diyakini perlu dan penting untuk dilakukan oleh sekolah dan stakeholders-nya untuk menjadi pijakan dalam penyelenggarakan nilai cinta tanah air di sekolah. Tumbuh dan berkembangnya nilai cinta tanah air akan mendorong anggota tumbuh dengan kapasitas dan komitmennya untuk 
Luthfiah

Internalisasi Nilai-Nilai Cinta Tanah Air pada Ekstrakurikuler Irmas Al Fikri di SMKN 1 Lemahabang

melakukan berbagai hal yang terbaik dan melakukan segalanya dengan benar dan memiliki tujuan hidup.

Hakikatnya cinta tanah air dan bangsa adalah kebanggaan menjadi salah satu bagian dari tanah air dan bangsanya yang berujung ingin berbuat sesuatu yang mengharumkan nama tanah air dan bangsa.

Internalisasi nilai cinta tanah air tidak bisa dilakukan secara instan atau sekaligus kepada setiap anggota. Proses internalisasi nilai pendidikan karakter cinta tanah air tersebut membutuhkan pembiasaan diri untuk masuk ke dalam hati agar tumbuh dari dalam, menancap kuat dan mengakar di dalamnya. Dengan selalu membiasakan kegiatan yang sudah dijelaskan di atas maka nilai cinta tanah air akan terbentuk.

Sebagaimana yang telah dijelaskan pada pembahasan sebelumnya. Dalam pelaksanaan suatu kegiatan pasti ada faktor-faktor yang mendukung dan menghambat proses untuk mencapai hasil yang diharapkan. Begitu juga dengan pelaksanaan internalisasi nilai cinta tanah air melalui Irmas Al Fikri ini dalam proses pelaksanaannya, terdapat faktor-faktor pendukung baik dari warga sekolah, wali murid maupun stakeholders lingkungan sekitar sekolah. Hal tersebut mempermudah dalam menanamkan nilai cinta tanah air kepada anggota Irmas Al Fikri yang mana harapan dari pihak sekolah yaitu bisa menimbulkan dampak positif bagi anggota, bagi lingkungan sekolah maupun lingkungan masyarakat.

\section{KESIMPULAN}

Berdasarkan hasil penelitian tentang "Internalisasi Nilai Pendidikan Karakter Cinta Tanah Air pada Irmas Al Fikri di SMKN 1 Lemahabang”, dapat disimpulkan sebagai berikut:

1. Nilai-nilai cinta tanah air yang terinternalisasikan pada Irmas Al fikri sesuai dengan pendapat beberapa ahli yakni mencintai keberagamana/perbedaan, mengembangkan rasa kekeluargaan dengan semangat gotong royong, toleransi, peduli lingkungan, peduli sosial, dan tanggung jawab.

2. Strategi yang dilakukan Irmas Al Fikri dalam internalisasi nilai cinta tanah air melalui beberapa program kerja diantaranya kegiatan mentoring, kajian keindonesiaan, rihlah, bakti sosial, dan latihan dasar kepemimpinan.

3. Persepsi kognitif anggota Irmas Al Fikri tentang nilai cinta tanah air belum belum merata karena masih ada anggota yang belum memahami makna tentang pancasila yang menjadi dasar negara dan anggota tersebut tergolong malas mengikuti kegiatan.

Oleh sebab itu, diperlukan strategi tambahan agar persepsi kognitif anggota Irmas $\mathrm{Al}$ Fikri mengenai nilai cinta tanah air bisa terserap kedalam berbagai karakter anggota.

\section{BIBLIOGRAFI}

Albertus, Doni Koesoema. (2010). Pendidikan karakter: strategi mendidik anak di zaman global. Jakarta: PT. Grasindo. Google Schoolar

Ali, Said Ismail. (2010). Pelopor Pendidikan Islam Paling Berpengaruh. Jakarta: Pustaka Al-Kautsar. Google Schoolar

Azzel, Ahmad Muhaimin. (2011). Urgensi Pendidikan Karakter di Indonesia, Yogyakarta: PT. Ar-Ruzz Media. Google Schoolar

Creswell, John W. (2008). Educational research: Planning, conducting, and evaluating quantitative. Prentice Hall Upper Saddle River, NJ. Google Schoolar 
Luthfiah

Internalisasi Nilai-Nilai Cinta Tanah Air pada Ekstrakurikuler Irmas Al Fikri di SMKN 1 Lemahabang

Dja'far, Alamsyah M. (2015). Intoleransi kaum pelajar. Wahidinstitute. Org. Diakses Dari Http://Www. Wahidinstitute. Org/Wi-Id/Indeks-Opini/28o-Intoleransi-KaumPelajar. Html. Google Schoolar

Gunaryo, Ahmad. (2011). Transformasi Hukum Islam dalam Pembangunan Hukum Nasional. Makalah Disampaikan Pada Matrikulasi Mahasiswa Baru Program Doktor Ilmu Hukum Universitas Diponegoro, Kamis, 22. Google Schoolar

Hermawan, Iwan. (2019). Metode Penelitian Pendidikan: Kuantitatif, Kualitatif dan Mixed Metode. Jawa Barat: Hidayatul Qur'an Kuningan. Google Schoolar

JSH, Tim. (2020). Atalia Ajak Pelajar Se-Jawa Barat Berantas Hoaks dan Radikalisme. Platzdasch, Bernhard. (2009). Islamism in Indonesia. ISEAS Publishing. Google Schoolar Putra, Dalizar. (1995). “HAM”, Hak Asasi Manusia menurut Al Qur’an. Al Husna Zikra.

Saidi, Anas. (2016). Mahasiswa Islam dan Masa Depan Demokrasin di Indonesia. Google $\underline{\text { Schoolar }}$

Samani, Muchlas, \& Hariyanto, M. S. (2011). Konsep dan model pendidikan karakter. Bandung: Remaja Rosdakarya. Google Schoolar

Sekaran, Uma, \& Bougie, Roger. (2016). Research methods for business: A skill building approach. John Wiley \& Sons. Google Schoolar

Wicaksono, Hendro, \& Dermawan, Mohammad Kemal. (2020). Alat Ukur Tingkat Radikalisme Berdasarkan Penilaian Kepribadian. Deviance Jurnal Kriminologi, 4(1), 84-102. Google Schoolar 